\title{
ASSESSMENT OF CLINICAL BIOCHEMICAL PARAMETERS IN ROMA MINORITY RESIDING IN EASTERN SLOVAKIA COMPARED WITH THE MAJORITY POPULATION
}

\author{
Beáta Hubková1, 2, Jana Mašlanková1, Marek Stupák1, Juraj Guzy¹, Anna Kováčová2, Daniel Pella³, Peter \\ Jarčuška³, Mária Mareková'; HepaMeta Team* \\ ${ }^{1}$ Department of Medical and Clinical Biochemistry and LABMED, Faculty of Medicine, P. J. Šafárik University in Košice, Košice, Slovakia \\ 2Laboratory Diagnostics LABMED, Košice, Slovakia \\ ${ }^{31}$ st Department of Internal Medicine, Faculty of Medicine, P. J. Šafárik University in Košice, Košice, Slovakia
}

\section{SUMMARY}

Roma constitute the largest ethnic minority in Europe and the second largest minority in Slovakia. Their health problems originate mainly from their low socioeconomic status, certain cultural aspects and their health-threatening lifestyle as well as the psycho-social burden arising from poverty and frequent migration.

Evaluation of glucose, albumin, triacylglycerol (TAG) and low density lipoprotein cholesterol (LDL-C) concentrations did not reveal any clue about the presumed deteriorated health of the Roma population. Higher proportions of subjects with elevated serum total cholesterol were found in Roma women as compared to both control groups of women $(p=0.027, p=0.006)$ and in Roma men as compared to the male control group living in standard conditions. Only the low level of HDL-cholesterol gives a glimpse of their deteriorated health. Significantly lower levels of serum HDL-C were reported in Roma men and women compared to the respondents in both control groups with a $p$ value of $p<0.001$.

Comparing the ratio of LDL-C/HDL-C yielded significant differences between the number of physiological values in Roma men and men from the control group $1(p=0.022)$ in favour of the control group.

When comparing the number of people with physiological values of cholesterols and with worsening TAG parameters at the same time, the increased risk of Roma men compared with men from the control group 1 became evident, with a level of significance of $p=0.023$.

Evaluation of urine samples pointed to significantly higher concentrations of urinary protein in Roma women compared with women in the control group $1(p=0.012)$.

Key words: Roma, health status, glucose, cholesterol, triacylglycerol, high-density lipoprotein-cholesterol, low-density lipoprotein-cholesterol

Address for correspondence: M. Mareková, Department of Medical and Clinical Biochemistry, P. J. Šafárik University in Košice, Tr. SNP 1, 040 11, Košice, Slovakia. E-mail: maria.marekova@upjs.sk

\section{INTRODUCTION}

Roma constitute the largest ethnic minority in Europe $(1,2)$ Over 8 million Roma live across Europe, with the largest communities residing in Romania, Bulgaria, Spain, Hungary, and Slovakia (3-5). The exact number of Roma living in Slovakia is not known since they often do not report their Roma origins. According to the "Summary Report on Roma" from 2002, their number in the Slovak Republic was estimated to be 365,000 , with an expected increase to 515,000 by 2020 , given the current population curve (6). From a geographical point of view, most Roma in Slovakia live in the southern part of central and eastern Slovakia, mainly in separated and segregated settlements (7-10).

Roma history dates back to the period after the resettlement of poor nomads from the Indian peninsula in the 9-13th century. In the first years after they entered Europe, they were initially

\footnotetext{
*HepaMeta Team members are listed in Appendix
}

received hospitably. The situation changed after their excommunication by the Catholic Church in the 15th century. Their persecution culminated during World War II, and the violent and often unprofessional assimilation of Roma after 1945 did not improve their situation.

Roma often were and continue to be labelled as socially backward people in need of basic re-education regarding social and hygienic issues (6). Their health risks are based on their low socioeconomic status, certain cultural aspects and their healththreatening lifestyle as well as the psycho-social burdens arising from poverty and frequent migration $(1,2,11-17)$. The results of studies by Carrasco-Garrido et al. (5) and Dolinská et al. (18) point out, for example, that Roma women are more likely to suffer from obesity than non-Roma women.

Every culture has its own specifics, reflected in the lifestyle of its members. Analyses in clinical biochemistry are designed to assess health status and to allow on-going pathological processes of living systems to be defined and changes in specifications of parameters to be proposed. 
The aim of the present work was to investigate a panel of basic biochemical parameters (available also at the outpatient clinics of general practitioners) of Roma in appropriate control groups: the control group 1 - people living in the vicinity of segregated Roma and presumably in similar conditions as the Roma; and the control group 2 - living outside of these communities, presumably in standard conditions of eastern Slovakia. The following serum and urinary parameters were involved in the present study: glucose, lipid profile (with calculated LDL values), serum albumin, urinary glucose, ketone bodies, and proteins.

A broader aim of this study is to answer the question whether the health status of Roma has improved after the efforts of relevant bodies from the European Union. The results in perspective could serve the competent national authorities to prepare and implement appropriate measures in the field of public health.

\section{MATERIALS AND METHODS}

\section{Respondents}

Respondent recruitment methods are described in detail by Madarasová Gecková et al. (19). The respondents of the HepaMeta project $(\mathrm{N}=855 ; 344$ men and 511 women) were divided according to the place of residence into three following categories:

- 1st category: people from segregated Roma communities, identified as Roma ( $\mathrm{N}=422 ; 155$ men and 267 women);

- 2nd category: people living in the vicinity of segregated Roma communities, constituting control group $1(\mathrm{~N}=134 ; 63$ men and 71 women);

- 3rd category: people living outside the area of segregated Roma communities, constituting control group $2(\mathrm{~N}=219 ; 111$ men and 108 women).

The basic biochemical parameters of Roma were compared with the results of people of the control group 1 and 2, which served as comparative values. The reason of setting two control groups was to preclude the adverse environmental impact on the health status of Roma living in the studied area. Of the initial 855 respondents, 775 (329 men and 446 women) fulfilled all criteria and were included in the analysis.

The study was approved by the Ethics Committee of the P. J. Šafárik University in Košice. Participation in the study was fully voluntary and anonymous. Detailed information about the study and its procedures was given to all respondents, and informed consent was obtained prior to the medical examination.

\section{Material Collection for Biochemical Measurements \\ Serum glucose, total cholesterol (TC), low-density lipoprotein- cholesterol (LDL-C) triacylglycerols (TG) and high-density lipoprotein-cholesterol (HDL-C) were examined. All endpoints were determined by the selective biochemical analyser ADVIA 2400, Siemens - Bayer. Selected diagnostic criteria for metabolic syndrome (MS) and cardiovascular disease (CVD) risk factor used in the study are listed in paper by Madarasová Gecková et al. (19). \\ Urine proteins, glucose and ketone bodies were evaluated semi- quantitatively using the 10 parameter urine strip test Dekaphan Leuco (Erba Lachema, CZ).}

\section{Data Analysis}

Differences between group means were performed by analysis of variance (ANOVA) with a multiple comparison post testing (Tukey).

Additional data analysis was performed by statistical evaluation expressed in significance of differences in the number of physiological values of selected biochemical parameters in Roma and the control groups, using Pearson's chi-square test.

Because of the large number of analyses, $p$ value $<0.001$ was estimated as being statistically significant. Means, standard deviations, medians and ranges are reported in terms of original distributions. Results are summarised in Tables 1-4.

\section{RESULTS}

\section{Ethnic and Age Composition of Probands}

The study group consisted of 422 subjects of Roma origin (155 men and 267 women). A total of 353 probands were subdivided into the control categories according to the inclusion criteria described in the methodology. 134 subjects who formed the control group 1 and 219 probands of the control group 2 represented $46 \%$ of all probands. Mean age of probands was 34.1 years $(\mathrm{SD} \pm 8.4)$, ranging from 18 to 55 years of age.

\section{Overview of Selected Serum and Urinary Parameters}

The greatest variance in values of serum glucose was observed in Roma with a range of 3.0-14.6 mmol/l; values in the control groups ranged between $3.7-9.8 \mathrm{mmol} / \mathrm{l}$. Nevertheless, the median value of the serum glucose level was lower among Roma when compared with the control group 2. Serum albumin means indicated significant differences in values for Roma women and women in the control group 1 (Table 1). The lowest values of serum TC levels were recorded in Roma men, with a maximum value of $7.4 \mathrm{mmol} / \mathrm{l}$. The maximum level of TC in Roma women, which was one of the highest of all values, was $8.7 \mathrm{mmol} / 1$. Despite this fact, the mean value of TC in women as well as in men was one of the lowest values $(4.8 \mathrm{mmol} / \mathrm{l}$ and $4.7 \mathrm{mmol} / \mathrm{l}$ in women and men, respectively) and was significantly lower when compared to men in the control group 2 and women in the control group 1 (Table 1). The difference in serum TG levels was significant when comparing the values for men and women, regardless of their origin, with higher values in men than in women. Mean values were as follows: $1.5 \mathrm{mmol} / 1,1.4 \mathrm{mmol} / 1,1.3 \mathrm{mmol} / 1$ in Roma men, men in the control group 1 and in the control group 2, respectively; and $1.2 \mathrm{mmol} / 1,1.1 \mathrm{mmol} / 1,1.2 \mathrm{mmol} / 1$ in Roma women, and women in the control groups 1 and 2, respectively. Conversely, significantly lower levels of serum HDL-C were reported in Roma men and women compared to the respondents in both control groups with a $p$ value of $p<0.001$. High values with a median of $1.4 \mathrm{mmol} / \mathrm{l}$ exceeding the physiological range were observed in women from the control groups. The mean value of LDL-C level was within physiological ranges in the total study group, nevertheless, statistically significant difference was reported in Roma men and men in the control group 1 (Table 1).

Interesting although not surprising is the result of semi-quantitative evaluation of urine samples. The highest concentrations of 
urinary protein $(5 \mathrm{~g} / \mathrm{l})$ were observed in women, more specifically in Roma women. Maximum levels of $15 \mathrm{mmol} / \mathrm{l}$ urinary ketone bodies were observed among both Roma women and women from the control group 2 .

\section{DISCUSSION}

\section{Blood and Urinary Glucose}

Vozarova de Courten et al. (21) conducted a study on the Roma living in western Slovakia. Their study involved 156 Roma people and 501 people from the majority population and found a much higher prevalence of type 2 diabetes mellitus, metabolic syndrome and cardiovascular disease. These results are consistent with those of Carrasco-Garrido et al. (5) who claim that 7\% of Roma in Spain have diabetes mellitus type 2.

Results of determination of serum glucose levels of Roma in eastern Slovakia compared with both control groups did not indicate significant differences (Table 1).

Physiological levels of serum glucose (Table 2) were observed in $90 \%$ of Roma men ( $10 \%$ with pathologically increased glucose) and in $89 \%$ of Roma women (4\% with pathologically increased glucose). Statistically significant was the difference in number of probands with physiological values among Roma men and men in the control group $2(\mathrm{p}=0.040)$ and among Roma women and women in the control group $2(p=0.009)$. None of these subjects had glucose concentration above $1.4 \mathrm{mmol} / \mathrm{l}$ detected in their urine.

Difference in number of probands with physiological values of urinary glucose was not significant (Table 2). High maximum levels of urinary glucose were observed in Roma women as well as in men (both $55 \mathrm{mmol} / \mathrm{l}$ ), which did not necessarily indicate an increased prevalence of diabetes, but rather pointed to a noncompensated disease resulting from neglect of medical check-ups.

Urinary ketone bodies were observed among men, Roma women and women from the control group 2 which draw attention not only to ketosis but probably also to the deliberate starvation of women in the control group prior to urine collection (Table 2).

\section{Parameters of Lipid Metabolism}

According to Carrasco-Garrido et al. (5) and Vozarova de Courten et al. (21) Spanish Roma women as well as the Roma in western Slovakia are more likely to suffer from obesity than the majority population. In contrast to their findings, the Roma population in eastern Slovakia is apparently not suffering from obesity as indicated by the results of Babinska et al. (22). Differences may

Table 1. Basic biochemical parameters of Roma and non-Roma

\begin{tabular}{|c|c|c|c|c|c|c|}
\hline & \multicolumn{3}{|c|}{ Men } & \multicolumn{3}{|c|}{ Women } \\
\hline & $\begin{array}{l}\text { Roma } \\
\mathrm{N}=155\end{array}$ & $\begin{array}{l}\text { CG } 1 \\
N=63\end{array}$ & $\begin{array}{c}\mathrm{CG} 2 \\
\mathrm{~N}=111\end{array}$ & $\begin{array}{l}\text { Roma } \\
\mathrm{N}=267\end{array}$ & $\begin{array}{l}\text { CG } 1 \\
\mathrm{~N}=71\end{array}$ & $\begin{array}{c}C G 2 \\
N=108\end{array}$ \\
\hline Serum glucose ${ }^{1}(\mathrm{mmol} / \mathrm{l})$ & $4.8 \pm 0.7$ & $4.8 \pm 0.6$ & $5.0 \pm 0.7$ & $4.6 \pm 0.7$ & $4.6 \pm 0.5$ & $4.8 \pm 0.5$ \\
\hline Serum albumin (g/l) & $47.7 \pm 2.6$ & $48.1 \pm 2.6$ & $47.7 \pm 2.5$ & $46.0 \pm 2.7$ & $47.2 \pm 4.3^{*}$ & $46.2 \pm 2.4$ \\
\hline Serum TC (mmol/l) & $4.7 \pm 1.0$ & $5.0 \pm 1.1$ & $5.2 \pm 1.0^{* \star *}$ & $4.8 \pm 1.0$ & $5.2 \pm 0.8^{*}$ & $5.1 \pm 0.9$ \\
\hline Serum TG (mmol/l) & $1.5 \pm 1.0$ & $1.4 \pm 1.2$ & $1.3 \pm 0.7$ & $1.2 \pm 0.8$ & $1.1 \pm 0.7$ & $1.2 \pm 0.7$ \\
\hline $\mathrm{HDL}-\mathrm{C}^{1}(\mathrm{mmol} / \mathrm{l})$ & $1.0 \pm 0.4$ & $1.2 \pm 0.3^{* * *}$ & $1.1 \pm 0.3^{* * *}$ & $1.1 \pm 0.3$ & $1.4 \pm 0.4^{\star \star *}$ & $1.4 \pm 0.5^{\star \star *}$ \\
\hline LDL-C (mmol/l) & $2.5 \pm 0.7$ & $2.6 \pm 0.8$ & $2.8 \pm 0.7^{\star *}$ & $2.5 \pm 0.7$ & $2.7 \pm 0.6$ & $2.5 \pm 0.6$ \\
\hline
\end{tabular}

CG 1 = control group $1 ;$ CG 2 = control group $2, \mathrm{~ns}$ - statistically not significant difference

Values are reported as mean \pm SD unless otherwise indicated

${ }^{1}$ Median \pm IQR

Asterisks indicate significant differences (adjusted for sex) between Roma's and non-Roma's (ANOVA, Turkey Multiple Comparison post testing)

${ }^{*} \mathrm{p}<0.05 ;{ }^{* *} \mathrm{p}<0.01 ;{ }^{* * *} \mathrm{p}<0.001$

Table 2. Prevalence of probands with physiological values of basic biochemical parameters

\begin{tabular}{|l|c|c|c|c|c|c|c|c|c|c|}
\hline & \multicolumn{3}{|c}{ Men } & \multicolumn{4}{c|}{ Women } \\
\cline { 2 - 12 } & $\begin{array}{l}\text { Roma } \\
\text { N=155 }\end{array}$ & $\begin{array}{c}\text { CG 1 } \\
\text { N=63 }\end{array}$ & p value & $\begin{array}{c}\text { CG 2 } \\
\text { N=111 }\end{array}$ & p value & $\begin{array}{c}\text { Roma } \\
\text { N=267 }\end{array}$ & $\begin{array}{c}\text { CG 1 } \\
\text { N=71 }\end{array}$ & p value & $\begin{array}{c}\text { CG 2 } \\
\text { N=108 }\end{array}$ & p value \\
\hline Serum glucose & $90 \%$ & $94 \%$ & $\mathrm{~ns}$ & $96 \%$ & 0.040 & $89 \%$ & $90 \%$ & $\mathrm{~ns}$ & $97 \%$ & 0.009 \\
\hline Serum albumin & $90 \%$ & $89 \%$ & $\mathrm{~ns}$ & $90 \%$ & $\mathrm{~ns}$ & $97 \%$ & $93 \%$ & $\mathrm{~ns}$ & $98 \%$ & $\mathrm{~ns}$ \\
\hline Serum TC & $69 \%$ & $63 \%$ & $\mathrm{~ns}$ & $53 \%$ & 0,008 & $67 \%$ & $49 \%$ & 0,006 & $58 \%$ & $\mathrm{~ns}$ \\
\hline Serum TG & $81 \%$ & $83 \%$ & $\mathrm{~ns}$ & $84 \%$ & $\mathrm{~ns}$ & $90 \%$ & $92 \%$ & $\mathrm{~ns}$ & $92 \%$ & $\mathrm{~ns}$ \\
\hline HDL-C & $33 \%$ & $62 \%$ & $<0.001$ & $56 \%$ & $<0.001$ & $32 \%$ & $51 \%$ & 0.004 & $41 \%$ & $\mathrm{~ns}$ \\
\hline LDL-C & $91 \%$ & $84 \%$ & $\mathrm{~ns}$ & $87 \%$ & $\mathrm{~ns}$ & $92 \%$ & $90 \%$ & $\mathrm{~ns}$ & $94 \%$ & $\mathrm{~ns}$ \\
\hline Urine proteins & $56 \%$ & $70 \%$ & $\mathrm{~ns}$ & $52 \%$ & $\mathrm{~ns}$ & $44 \%$ & $61 \%$ & 0.012 & $54 \%$ & $\mathrm{~ns}$ \\
\hline Urine glucose & $95 \%$ & $98 \%$ & $\mathrm{~ns}$ & $99 \%$ & $\mathrm{~ns}$ & $98 \%$ & $100 \%$ & $\mathrm{~ns}$ & $100 \%$ & $\mathrm{~ns}$ \\
\hline Urine ketone bodies & $97 \%$ & $95 \%$ & $\mathrm{~ns}$ & $97 \%$ & $\mathrm{~ns}$ & $98 \%$ & $99 \%$ & $\mathrm{~ns}$ & $97 \%$ & $\mathrm{~ns}$ \\
\hline
\end{tabular}

CG 1 = control group 1; CG 2 = control group 2, ns - statistically not significant difference 
arise as a result of uneven social situation in Slovakia. Vozarova de Courten et al. (21) reports a statistically significant difference in the level of serum TG in Roma residing in western Slovakia compared to the majority with $\mathrm{p}<0.001$. Zeljko et al. achieved among Croatian Roma similar results as Vozarova de Courten et al. in their study. Zeljko et al. point out $64 \%$ of pathological values of TC but better results of HDL-C in Croatian Roma than in the majority population $(21,23)$.

In this study, physiological values of TC were observed in $69 \%$ of Roma men and $67 \%$ of Roma women (Table 2). The data observed in the control group were significantly lower: $53 \%$ $(p=0.008)$ men in the control group 2 and only $49 \%(p=0.006)$ women in the control group 1 had physiological values of the examined parameter (Table 2).

The difference in number of subjects with physiological levels of TG did not vary in Roma and non-Roma but pointed to a deteriorated health of the whole study group (Table 2).

When evaluating the number of probands with physiological values of TC and pathological values of TG at the same time, significantly higher number of Roma men compared to men in the control group 1 was observed (Table 3). As indicated above, number of respondents with pathological values of TG itself did not show differences between Roma and non-Roma, differences have emerged after adjustment for serum cholesterol, emphasizing the importance of TG even at physiological values of TC, similarly as pointed out in the work of Cambien et al. (24).

Among men, the highest percentages of pathological values of both TC and TG (20\%) were detected in the control group 2, i.e. in the non-Roma population living far from the Roma settlements (Table 3). Among women, no variations were observed between the individual groups.

The values of HDL-C level in Roma are alarming. Statistical analysis pointed to statistically significant differences between number of probands with physiological HDL-C in Roma men and men in both control groups, with a significance level of $\mathrm{p}<0.001$, while a significance of $\mathrm{p}=0.004$ was observed by comparison of HDL-C levels of Roma women and women from the control group 1 (Table 2). One of the possible reasons of higher occurrence of pathological values may be genetic predisposition of the Roma population, similar to the confirmed genetic propensity of Roma to renal failure (25) or to various risk of cardiovascular diseases confirmed among ethnic minorities in Canada (26). The second may be regular alcohol consumption, which significantly affects the levels of the mentioned parameters, thus increases the risk of cardiovascular disease development.
Although it is still not part of the National Cholesterol European Program (NCEP) guidelines, the balance between LDL and HDL is considered as a key marker of cardiovascular risk, making the LDL-C/HDL-C ratio a valuable tool for the assessment and clinical management of individuals at risk for heart disease (27-30). Several large epidemiological and clinical studies have found the LDL-C/HDL-C ratio to be an excellent predictor of coronary heart disease (CHD) among those with elevated TG levels (28) and in elderly people (20). Earlier studies evaluating the impact of dietary cholesterol on serum cholesterol focused on TC as the primary marker for risk, but recent studies have shown that dietary cholesterol increases both LDL-C and HDL-C with little change in the LDL-C/HDL-C ratio $(31,32)$. Evaluation of LDL-C/HDL$\mathrm{C}$ in the present study showed a significant difference between Roma men and men from the control group $1(\mathrm{p}=0.022)$ (Table 3$)$.

\section{Parameters of Protein Metabolism}

Chronic kidney disease affects a significant portion of the world population, with a prevalence of $7.2 \%$ in adults over age 30 and dramatically increasing to $23.4-35.8 \%$ over age 65 (33). It is estimated that the exact number of CKD patients at least double the number of clinically treated patients, and this fact negatively contributes to the process of successful cure and induction of the state of remission. The evidence of possible patients with nephropathy results in a closer comparison of serum and urine glucose as well as comparison of serum TC level and urine protein level. A study by Kol'vek et al. (25) shows that the risk of end-stage renal disease is significantly higher among Roma than among nonRoma, probably due to their genetic propensity to renal failure.

The presence of proteins in urine of Roma women is represented by a maximum value of $5 \mathrm{~g} / 1$ and median $0.3 \mathrm{~g} / \mathrm{l}(\mathrm{p}=0.012)$ (Table 2). In $2 \%$ of Roma women an elevated level of urine glucose was recorded. The protein presence in urine is believed to be related to inadequate hygiene habits in Roma woman or improper collection of biological material by probands. Results of physiological values of serum TC level and pathological values of urinary protein level at the same time draw attention to the following significant differences: $p=0.021$ and $p=0.045$ between Roma men and men in the control group 1 and 2, respectively; $\mathrm{p}=0.004$ between Roma women and women from the control group 2; $<<0.001$ between Roma women and women from the control group 1 (Table 4).

Our findings suggested a higher presence of protein in urine of Roma women, which is probably caused by their unhealthy

Table 3. Prevalence of probands with pathological values of auxiliary biochemical parameters

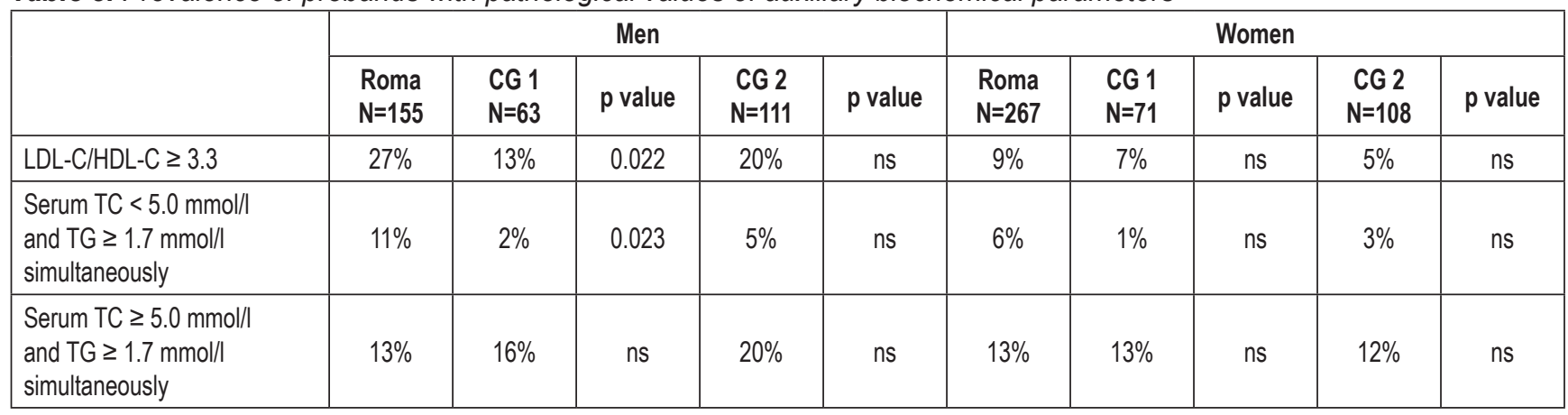

CG 1 = control group 1; CG 2 = control group 2; ns - statistically not significant difference 
Table 4. Prevalence of probands with some CKD risk factors*

\begin{tabular}{|c|c|c|c|c|c|c|c|c|c|c|}
\hline & \multicolumn{5}{|c|}{ Men } & \multicolumn{5}{|c|}{ Women } \\
\hline & $\begin{array}{l}\text { Roma } \\
\mathrm{N}=155\end{array}$ & $\begin{array}{l}\mathrm{CG} 1 \\
\mathrm{~N}=63\end{array}$ & $p$ value & $\begin{array}{c}\begin{array}{c}\text { CG } 2 \\
\mathrm{~N}=111\end{array}\end{array}$ & $p$ value & $\begin{array}{l}\text { Roma } \\
\mathrm{N}=267\end{array}$ & $\begin{array}{l}\text { CG } 1 \\
\mathrm{~N}=71\end{array}$ & $p$ value & $\begin{array}{c}C G 2 \\
\mathrm{~N}=108\end{array}$ & $p$ value \\
\hline $\begin{array}{l}\text { Serum glucose }>6.2 \mathrm{mmol} / \mathrm{l} \\
\text { and urine glucose }>1.4 \mathrm{mmol} / \mathrm{l} \\
\text { simultaneously }\end{array}$ & $3 \%$ & $0 \%$ & ns & $1 \%$ & ns & $0 \%$ & $0 \%$ & ns & $0 \%$ & ns \\
\hline $\begin{array}{l}\text { Serum glucose } \leq 6.2 \mathrm{mmol} / \mathrm{l} \\
\text { and urine glucose }>1.4 \mathrm{mmol} / \mathrm{l} \\
\text { simultaneously }\end{array}$ & $2 \%$ & $2 \%$ & ns & $0 \%$ & ns & $2 \%$ & $0 \%$ & ns & $0 \%$ & ns \\
\hline $\begin{array}{l}\text { Serum TC }>5.2 \mathrm{mmol} / \mathrm{l} \\
\text { and urine protein }>0.15 \mathrm{~g} / \mathrm{l} \\
\text { simultaneously }\end{array}$ & $8 \%$ & $11 \%$ & ns & $24 \%$ & ns & $15 \%$ & $20 \%$ & ns & $20 \%$ & ns \\
\hline $\begin{array}{l}\text { Serum TC } \leq 5.2 \mathrm{mmol} / \mathrm{l} \\
\text { and urine protein }>0.15 \mathrm{~g} / \mathrm{l} \\
\text { simultaneously }\end{array}$ & $35 \%$ & $19 \%$ & 0.021 & $23 \%$ & 0.045 & $42 \%$ & $20 \%$ & $<0.001$ & $26 \%$ & 0.004 \\
\hline
\end{tabular}

*based on the relationship of selected serum and urine parameters

CG 1 = control group 1; CG 2 = control group 2; ns - statistically not significant difference

lifestyle as well as psycho-social burdens arising from poverty and frequent migration.

\section{Acknowledgement}

This work was supported by the Agency of the Slovak Ministry of Education for the Structural Funds of EU, DIAGONKO-ITMS: 26220220153 (30\%), CEMIO-ITMS: 26220120058, activity 1.4. (20\%), and CEEPMITMS: 26220120067 activity $1.4(20 \%)$. This paper was also partially funded by VEGA: 1/0999/11 (30\%), the PhD Grant System of PJŠ University in Košice: 6/GSD/2011, the Visegrad fund: 123456-0128, and Roche Slovensko, s. r. o.

\section{Conflict of Interests}

None declared

\section{APPENDIX}

HepaMeta Team: Peter Jarčuška, Andrea Madarasová Gecková, Mária Mareková, Daniel Pella, Leonard Siegfried, Pavol Jarčuška, Lýdia Pastvová, Ján Fedačko, Jana Kollárová, Peter Kolarčik, Daniela Bobáková, Zuzana Veselská, Ingrid Babinská, Sylvia Dražilová, Jaroslav Rosenberger, Ivan Schréter, Pavol Kristian, Eduard Veselíny, Martin Janičko, Ladislav Virág, Anna Birková, Marta Kmet’ová, Monika Halánová, Darina Petrášová, Katarína Cáriková, Viera Lovayová, Lucia Merkovská, Lucia Jedličková, Ivana Valková

\section{REFERENCES}

1. Kósa Z, Széles G, Kardos L, Kósa K, Németh R, Országh S, et al. A comparative health survey of the inhabitants of Roma settlements in Hungary. Am J Public Health. 2007 May;97(5):853-9.

2. Kósa K, Daragó L, Adány R. Environmental survey of segregated habitats of Roma in Hungary: a way to be empowering and reliable in minority research. Eur J Public Health. 2011 Aug;21(4):463-8.

3. Hajioff S, McKee M. The health of the Roma people: a review of the published literature. J Epidemiol Community Health. 2000 Nov;54(11):864-9.

4. Hancock IF. We are the Romani people. Hatfield: University of Hertfordshire Press; 2005.
5. Carrasco-Garrido P, López de Andrés A, Hernández Barrera V, JiménezTrujillo I, Jiménez-García R. Health status of Roma women in Spain. Eur J Public Health. 2011 Dec;21(6):793-8.

6. Kumanová Z, Mann AB, Petrasová A, Šimčáková-Tóthová M. Romanies. Bratislava: Nadácia Milana Šimečku; 2006. (In Slovak.)

7. Kolarcik P, Madarasova Geckova A, Orosova O, van Dijk JP, Reijneveld SA. To what extent does socioeconomic status explain differences in health between Roma and non-Roma adolescents in Slovakia? Soc Sci Med. 2009 Apr;68(7):1279-84.

8. Rimárová K. The Health of the Roma people in Central and Eastern Europe. Košice: Pavol Jozef Šafárik University; 2010.

9. Vaňo B. Projection of Roma population in Slovakia until 2025. Bratislava: Institute of Informatics and Statistics; 2002.

10. Slušná L'. Slovakia: healthy communities. In: Koller T, editor. Poverty and social exclusion in the WHO European Region: health systems respond. Copenhagen: WHO Regional Office for Europe; 2010. p. 167-77.

11. Petek D, Rotar Pavlič D, Švab I, Lolić D. Attitudes of Roma toward smoking: qualitative study in Slovenia. Croat Med J. 2006 Apr;47(2):344-7.

12. Parry G, Van Cleemput P, Peters J, Walters S, Thomas K, Cooper C. Health status of Gypsies and Travellers in England. J Epidemiol Community Health. 2007 Mar;61(3):198-204. Erratum in: J Epidemiol Community Health. 2007 Jun;61(6):559.

13. Kanapeckiene V, Valinteliene R, Berzanskyte A, Kevalas R, Supranowicz P. Health of Roma children in Vilnius and Ventspils. Medicina (Kaunas). 2009;45(2):153-61.

14. Rambousková J, Dlouhý P, Křížová E, Procházka B, Hrnčířová D, Anděl M. Health behaviors, nutritional status, and anthropometric parameters of Roma and non-Roma mothers and their infants in the Czech Republic. J Nutr Educ Behav. 2009 Jan-Feb;41(1):58-64.

15. Hujová Z, Alberty R, Ahlers I, Ahlersová E, Paulíková E, Desatníková J, et al. Cardiovascular risk predictors in Central Slovakian Roma children and adolescents: regional differences. Cent Eur J Public Health. 2010 Sep;18(3):139-44.

16. Masseria C, Mladovsky P, Hernández-Quevedo C. The socio-economic determinants of the health status of Roma in comparison with nonRoma in Bulgaria, Hungary and Romania. Eur J Public Health. 2010 Oct;20(5):549-54.

17. Kohler IV, Preston SH. Ethnic and religious differentials in Bulgarian mortality, 1993-98. Popul Stud (Camb). 2011 Mar;65(1):91-113.

18. Dolinska S, Kudlackova M, Ginter E. The prevalence of female obesity in the world and in the Slovak Gypsy women. Bratisl Lek Listy. 2007;108(45):207-11.

19. Madarasová Gecková A, Jarčuška P, Mareková M, Pella D, Siegfried L, Jarčuška P, et al.; HepaMeta Team. HepaMeta - Prevalence of hepatitis $\mathrm{B} / \mathrm{C}$ and metabolic syndrome in population living in separated and segregated Roma settlements: a methodology for a cross-sectional populationbased study using community-based approach. Cent Eur J Public Health. 2014 Mar;22 Suppl:S6-11.

20. Packard CJ, Ford I, Robertson M, Shepherd J, Blauw GJ, Murphy MB, et al.; PROSPER Study Group. Plasma lipoproteins and apolipoproteins as predictors of cardiovascular risk and treatment benefit in the PROspective 
Study of Pravastatin in the Elderly at Risk (PROSPER). Circulation. 2005 Nov 15;112(20):3058-65.

21. Vozarova de Courten B, de Courten M, Hanson RL, Zahorakova A, Egyenes HP, Tataranni PA, et al. Higher prevalence of type 2 diabetes, metabolic syndrome and cardiovascular diseases in gypsies than in nongypsies in Slovakia. Diabetes Res Clin Pract. 2003 Nov;62(2):95-103.

22. Babinska I, Dankulincova Veselska Z, Bobakova D, Pella D, Panico S, Reijneveld SA, et al.; HEPA-META team. Is the cardiovascular risk profile of people living in Roma settlements worse in comparison with the majority population in Slovakia? Int J Public Health. 2013 Jun;58(3):417-25.

23. Zeljko HM, Skarić-Jurić T, Narančić NS, Barešić A, Tomas Z, Petranović $\mathrm{MZ}$, et al. Age trends in prevalence of cardiovascular risk factors in Roma minority population of Croatia. Econ Hum Biol. 2013 Jul;11(3):326-36.

24. Cambien F, Jacqueson A, Richard JL, Warnet JM, Ducimetiere P, Claude JR. Is the level of serum triglyceride a significant predictor of coronary death in "normocholesterolemic" subjects? The Paris Prospective Study. Am J Epidemiol. 1986 Oct;124(4):624-32.

25. Kolvek G, Rosicova K, Rosenberger J, Podracka L, Stewart RE, Nagyova $\mathrm{I}$, et al. End-stage renal disease among Roma and non-Roma: Roma are at risk. Int J Public Health. 2012 Aug;57(4):751-4.

26. Anand SS, Yusuf S, Vuksan V, Devanesen S, Teo KK, Montague PA, et al. Differences in risk factors, atherosclerosis, and cardiovascular disease between ethnic groups in Canada: the Study of Health Assessment and Risk in Ethnic groups (SHARE). Lancet. 2000 Jul 22;356(9226):279-84.

27. Fernandez ML, Webb D. The LDL to HDL cholesterol ratio as a valuable tool to evaluate coronary heart disease risk. J Am Coll Nutr. 2008 Feb;27(1):1-5.
28. Manninen V, Tenkanen L, Koskinen P, Huttunen JK, Mänttäri M, Heinonen OP, et al. Joint effects of serum triglyceride and LDL cholesterol and HDL cholesterol concentrations on coronary heart disease risk in the Helsinki Heart Study. Implications for treatment. Circulation. 1992 Jan;85(1):37-45.

29. Kannel WB. Risk stratification of dyslipidemia: insights from the Framingham Study. Curr Med Chem Cardiovasc Hematol Agents. 2005 Jul;3(3):187-93.

30. Cullen P, Schulte H, Assmann G. The Münster Heart Study (PROCAM): total mortality in middle-aged men is increased at low total and LDL cholesterol concentrations in smokers but not in nonsmokers. Circulation. 1997 Oct 7;96(7):2128-36.

31. Greene CM, Zern TL, Wood RJ, Shrestha S, Aggarwal D, Sharman MJ, et al. Maintenance of the LDL cholesterol:HDL cholesterol ratio in an elderly population given a dietary cholesterol challenge. J Nutr. 2005 Dec;135(12):2793-8.

32. Herron KL, Vega-Lopez S, Conde K, Ramjiganesh T, Roy S, Shachter NS, et al. Pre-menopausal women, classified as hypo- or hyperresponders, do not alter their LDL/HDL ratio following a high dietary cholesterol challenge. J Am Coll Nutr. 2002 Jun;21(3):250-8

33. Levey AS, Eckardt KU, Tsukamoto Y, Levin A, Coresh J, Rossert J, et al. Definition and classification of chronic kidney disease: a position statement from Kidney Disease: Improving Global Outcomes (KDIGO). Kidney Int. 2005 Jun;67(6):2089-100. 